\title{
DOTA-PESIN, a DOTA-conjugated bombesin derivative designed for the imaging and targeted radionuclide treatment of bombesin receptor-positive tumours
}

\author{
Hanwen Zhang • Jochen Schuhmacher • \\ Beatrice Waser • Damian Wild • Michael Eisenhut • \\ Jean Claude Reubi • Helmut R. Maecke
}

Received: 13 June 2006 / Accepted: 17 November 2006/ Published online: 30 January 2007

(C) Springer-Verlag 2007

\begin{abstract}
Purpose We aimed at designing and developing a novel bombesin analogue, DOTA-PEG4-BN(7-14) (DOTA-PESIN), with the goal of labelling it with ${ }^{67 / 68} \mathrm{Ga}$ and ${ }^{177} \mathrm{Lu}$ for diagnosis and radionuclide therapy of prostate and other human cancers overexpressing bombesin receptors.

Methods The 8-amino acid peptide bombesin (7-14) was coupled to the macrocyclic chelator DOTA via the spacer 15-amino-4,7,10,13-tetraoxapentadecanoic acid $\left(\mathrm{PEG}_{4}\right)$. The conjugate was complexed with $\mathrm{Ga}(\mathrm{III})$ and $\mathrm{Lu}(\mathrm{III})$ salts. The GRP receptor affinity and the bombesin receptor subtype profile were determined in human tumour specimens expressing the three bombesin receptor subtypes. Internalisation and efflux studies were performed with the human GRP receptor cell line PC-3. Xenografted nude mice were used for biodistribution.
\end{abstract}

\section{H. Zhang $\cdot$ H. R. Maecke $(\bowtie)$}

Division of Radiological Chemistry, Department of Radiology, University Hospital Basel,

Petersgraben 4,

4031 Basel, Switzerland

e-mail: hmaecke@uhbs.ch

J. Schuhmacher $\cdot$ M. Eisenhut

Department of Radiopharmaceutical Chemistry,

German Cancer Research Centre,

Heidelberg, Germany

B. Waser · J. C. Reubi

Division of Cell Biology and Experimental Cancer Research, Institute of Pathology, University of Berne,

P.O. Box 62, Murtenstrasse 31,

3010 Berne, Switzerland

D. Wild

Clinic and Institute of Nuclear Medicine,

Department of Radiology, University Hospital,

Basel, Switzerland
Results $\left[\mathrm{Ga}^{\mathrm{III}} / \mathrm{Lu}^{\mathrm{III}}\right]$-DOTA-PESIN showed good affinity to GRP and neuromedin $\mathrm{B}$ receptors but no affinity to BB3. $\left[{ }^{67} \mathrm{Ga} /{ }^{177} \mathrm{Lu}\right]$-DOTA-PESIN internalised rapidly into PC-3 cells whereas the efflux from PC-3 cells was relatively slow. In vivo experiments showed a high and specific tumour uptake and good retention of $\left[{ }^{67} \mathrm{Ga} /{ }^{177} \mathrm{Lu}\right]$-DOTAPESIN. $\left[{ }^{67} \mathrm{Ga} /{ }^{177} \mathrm{Lu}\right]$-DOTA-PESIN highly accumulated in GRP receptor-expressing mouse pancreas. The uptake specificity was demonstrated by blocking tumour uptake and pancreas uptake. Fast clearance was found from blood and all non-target organs except the kidneys. High tumourto-normal tissue ratios were achieved, which increased with time. PET imaging with $\left[{ }^{68} \mathrm{Ga}\right]$-DOTA-PESIN was successful in visualising the tumour at $1 \mathrm{~h}$ post injection. Planar scintigraphic imaging showed that the ${ }^{177}$ Lu-labelled peptide remained in the tumour even 3 days post injection. Conclusion The newly designed ligands have high potential with regard to PET and SPECT imaging with ${ }^{68 / 67} \mathrm{Ga}$ and targeted radionuclide therapy with ${ }^{177} \mathrm{Lu}$.

Keywords Gallium-68 - Lutetium-177 .

Bombesin receptors · Targeted radiotherapy

Prostate cancer

\section{Introduction}

Radionuclides coupled to receptor-specific peptides are currently under investigation in clinical trials involving different tumours [1]. They specifically localise receptors overexpressed on the plasma membrane and then internalise into cells [2-4]. The prototypes of these peptides are analogues of somatostatin [5].

In designing radiometal-based radiopeptides for cancer diagnosis and treatment, important factors to consider are 
half-life, mode of decay, cost and availability of the radionuclide. In diagnostic imaging [6], ${ }^{99 \mathrm{~m}} \mathrm{Tc},{ }^{123} \mathrm{I},{ }^{67} \mathrm{Ga}$ and ${ }^{111} \mathrm{In}$ are used for SPECT and ${ }^{18} \mathrm{~F},{ }^{11} \mathrm{C},{ }^{64} \mathrm{Cu}$ and ${ }^{68} \mathrm{Ga}$ for positron emission tomography (PET). ${ }^{177} \mathrm{Lu}$-labelled peptides have become attractive in targeted radiotherapy of small tumours or metastases owing to their excellent radiophysical properties and commercial availability of the radionuclide $[5,7,8] .{ }^{68} \mathrm{Ga}$, on the other hand, is a promising metallic positron emitter $\left(t_{1 / 2}=68 \mathrm{~min}, 89 \%\right.$, $\mathrm{E}_{\beta}{ }^{+}{ }_{\max }=1.90 \mathrm{MeV}$ ) for regular use in PET imaging because of its production from a ${ }^{68} \mathrm{Ga} /{ }^{68} \mathrm{Ge}$ generator, which allows independence from an on-site cyclotron and offers almost unlimited availability if two or three of these generators are used concomitantly as elution is possible every $3 \mathrm{~h}[9,10]$. To develop a ligand for the labelling with these two radionuclides would therefore seem promising.

In the field of radiolabelled peptides, bombesin (BN) analogues have become a promising class of ligands as gastrin-releasing peptide (GRP) receptors, a subtype of BN receptors, were found to be overexpressed on primary prostatic invasive carcinoma (and their invaded lymph nodes), breast tumours and gastrointestinal stromal tumours [11]. Up to now, many types of radiolabelled $\mathrm{BN}$ analogues have been designed to target GRP receptor-expressing tumours [12-24]. In particular, Van de Wiele et al. reported on a first study of prostate $(n=4)$ and breast cancer $(n=6)$ patients $[13,25]$. Their results showed that ${ }^{99 \mathrm{~m}} \mathrm{Tc}-\mathrm{RP} 527$ visualised four of six breast and one of four prostate carcinomas. This radiopeptide showed inferior properties to many other radiopeptides in the PC-3 tumour-bearing nude mouse model [26]. As ${ }^{99 \mathrm{~m}} \mathrm{Tc}-$ Demobesin $1\left(\left[{ }^{99 \mathrm{~m}} \mathrm{Tc}-\mathrm{N} 4^{0-1}\right.\right.$, bzlg $^{0}$,(D)Phe ${ }^{6}$, Leu-NHEt $^{13}$, des $^{\left.\left.-M_{\text {Met }}{ }^{14}\right] \mathrm{BN}(6-14)\right) \text { has }}$ shown higher affinity to the GRP receptor and a higher tumour accumulation in PC-3 tumour-bearing mice [27] than ${ }^{99 \mathrm{~m}} \mathrm{Tc}-\mathrm{RP} 527$, it may be a superior candidate for studying in patients.

We have recently developed DOTA $(1,4,7,10$-tetraazacyclododecane-1,4,7,10-tetraacetic acid)- and DTPA-modified (pan)BN radioligands having high affinity to all three human $\mathrm{BN}$ receptors [i.e. neuromedin B receptor (NMB-R), GRP-R and BN receptor subtype-3 (BB3)] [17]. Preliminary results in clinical studies of two of these radiopeptides have shown occasional uptake in the pancreas and relatively fast washout from lesions when labelled with ${ }^{111} \mathrm{In}$. The fast washout may be due to a low metabolic stability of these radiopeptides. Therefore, we set up a programme to synthesise BN-based radiopeptides with improved metabolic stability, an optimised tumour-to-kidney ratio and lack of affinity to BB3. From a series of peptides evaluated, DOTA-PEG 4 -BN(7-14) (DOTA-PESIN) looked particularly promising in our preclinical studies.

Here we present data on the synthesis and labelling of this peptide with the positron emitter ${ }^{68} \mathrm{Ga}$, the $\gamma$ - and
Auger electron emitter ${ }^{67} \mathrm{Ga}$ and the $\beta(\gamma)$-emitter ${ }^{177} \mathrm{Lu}$. In addition, we studied the receptor subtype affinity profile and the in vivo biodistribution of radiolabelled DOTAPESIN with regard to BN receptor subtypes. PET imaging and scintigraphy were also performed.

\section{Materials and methods}

All chemicals were obtained from commercial sources and used without further purification. Rink amide 4-methylbenzhydrylalanine (MBHA) resin and all Fmoc-protected amino acids are commercially available from NovaBiochem (Laeufelfingen, Switzerland). $\left[{ }^{67} \mathrm{Ga} \mathrm{Cl}_{3}\right.$ was purchased from Mallinckrodt Medical (Petten, the Netherlands) and $\left[{ }^{177} \mathrm{Lu}\right] \mathrm{Cl}_{3}$ from IDB (Petten, the Netherlands). Fmoc-15amino-4,7,10,13-tetraoxapentadecanoic acid (Fmoc- $\mathrm{PEG}_{4}$ $\mathrm{OH})$ was obtained from Quanta BioDesign (Powell, Ohio, USA) and 1,4,7,10-tetraazacyclododecane-1,4,7-tris(acetic acid-t-butyl ester)-10-acetic acid [DOTA-tris( ${ }^{\mathrm{t}} \mathrm{Bu}$ ester)] from Macrocyclics (Dallas, Texas, USA). Electrospray ionisation mass spectroscopy was carried out with a Finnigan SSQ 7,000 spectrometer (Bremen, Germany) and MALDI-MS measurement on a Voyager sSTR equipped with an Nd:YAG laser (Applied Biosystems, Framingham, USA). Ten milligrams of 3,5-dimethoxy-4-hydroxycinnamic acid were dissolved in $0.05 \%$ TFA of acetonitrile/ water $(1: 1)$ and used as matrix. Analytical high-performance liquid chromatography (HPLC) was performed on a Hewlett Packard 1050 HPLC system with a multiwavelength detector and a flow-through Berthold LB $506 \mathrm{Cl} \gamma$ detector (Regensdorf, Switzerland) using a Macherey-Nagel Nucleosil $120 \mathrm{C}_{18}$ column (Oensingen, Switzerland) (eluents: $\mathrm{A}=0.1 \%$ TFA in water and $\mathrm{B}=$ acetonitrile; gradient: 0-20 min, $80 \%-50 \%$ A; $21-24 \mathrm{~min}, 100 \% \mathrm{~B}$; $24-25 \mathrm{~min}$, $80 \%$ A). Preparative HPLC was performed on a Metrohm HPLC system LC-CaDI 22-14 (Herisau, Switzerland) with a Macherey-Nagel VP 250/21 Nucleosil $100-5 \mathrm{C}_{18}$ column (eluents: $\mathrm{A}=0.1 \%$ TFA in water and $\mathrm{B}=$ acetonitrile; gradient: $0-10 \mathrm{~min}, 70 \%-52 \% \mathrm{~A} ; 11-14 \mathrm{~min}, 100 \% \mathrm{~B}$; 14-15 min, $70 \%$ A). Quantitative $\gamma$-counting was performed on a COBRA $5003 \gamma$-system well counter from Packard Instruments (Meriden, CT, USA). Solid phase peptide synthesis was performed on a semiautomatic peptide synthesiser commercially available from Rink Combichem Technologies (Bubendorf, Switzerland). The cell culture medium was Dulbecco's minimal essential medium (DMEM) with $10 \%$ or $1 \%$ foetal calf serum (FCS) from BioConcept (Allschwil, Switzerland). PET imaging was performed on a Siemens ECAT EXACT $\mathrm{HR}^{+}$scanner (Siemens/CTI, Knoxville, TN, USA), and scintigraphic imaging was carried out on a PRISM 2000 XP camera (Philips, the Netherlands). ${ }^{68} \mathrm{Ga}$ was obtained from a 
${ }^{68} \mathrm{Ge} /{ }^{68} \mathrm{Ga}$ generator which consists of a column containing a self-made phenolic ion exchanger loaded with ${ }^{68} \mathrm{Ge}$ and coupled in series with a small anion exchanger column (AG $1 \times 8$ Cl-1, mesh 200-400; Bio-Rad, Munich, Germany) to concentrate ${ }^{68} \mathrm{Ga}$ during elution [28].

\section{Synthesis}

DOTA-PESIN was synthesised on solid support as described previously [17]. In brief, the peptide was assembled on a Rink amide MBHA resin according to classical Fmoc chemistry on a semi-automatic peptide synthesiser. Trityl and tert-butoxycarbonyl were used as side chainprotecting groups of His and Trp, respectively. Fmoc$\mathrm{PEG}_{4}-\mathrm{OH}$ (four equivalents) and DOTA-tris $(\mathrm{tBu})$ ester (three equivalents) were consecutively coupled to the peptide with HATU [1.2 equivalents based on Fmoc$\mathrm{PEG}_{4}-\mathrm{OH}$ or DOTA-tris(tBu) ester] as activating agent. Cleavage from the resin and deprotection as well as product purification and identification were performed according to a previously described protocol [17]. Calculated MW: 1573.81; MS-ES(-): $1610.3[\mathrm{M}+\mathrm{K}-\mathrm{H}]^{-}, 804.8[\mathrm{M}+\mathrm{K}-$ $2 \mathrm{H}]^{2-} ; \mathrm{MS}-\mathrm{ES}(+): 806.8[\mathrm{M}+\mathrm{K}+2 \mathrm{H}]^{2+} ; \mathrm{MALDI}, \mathrm{m} / \mathrm{z}(\%)$ : $1573.7\left(100,[\mathrm{M}+\mathrm{H}]^{+}\right), 1594.7\left(5,[\mathrm{M}+\mathrm{Na}]^{+}\right) ;$HPLC $\mathrm{t}_{\mathrm{R}}: 12.5$ min on analytical HPLC (purity: $>98 \%$ ).

$\left[G a^{I I I} / L u^{I I I}\right]$-DOTA-PESIN A mixture of DOTA-PESIN $(0.5 \mu \mathrm{mol})$ in $500 \mu \mathrm{l} 0.5 \mathrm{~mol} / \mathrm{l}$ ammonium acetate buffer (pH 5) was incubated with $1.5 \mu \mathrm{mol} \mathrm{Ga}\left(\mathrm{NO}_{3}\right)_{3} \cdot 9 \mathrm{H}_{2} \mathrm{O}$ or $\mathrm{Lu}$ $\left(\mathrm{NO}_{3}\right)_{3} \cdot 5 \mathrm{H}_{2} \mathrm{O}$ (in $0.04 \mathrm{~mol} / \mathrm{l} \mathrm{HCl}$ ) at $95^{\circ} \mathrm{C}$ for $25 \mathrm{~min}$, and purified over a SepPak $\mathrm{C}_{18}$ cartridge (Waters Corp., Milford, MA) preconditioned with $10 \mathrm{ml}$ ethanol and $10 \mathrm{ml}$ water. The cartridge was eluted with $10 \mathrm{ml}$ water followed by $3 \mathrm{ml}$ methanol, resulting in the metal ${ }^{\mathrm{III}}$-DOTApeptide after evaporation of methanol. The final product was analysed by analytical HPLC and MALDI. [Ga $a^{I I I}$ DOTA-PESIN (calculated MW): 1640.51; MALDI, m/z (\%): $1641.7\left(100,[\mathrm{M}+\mathrm{H}]^{+}\right), 1663.6\left(20,[\mathrm{M}+\mathrm{Na}]^{+}\right)$; HPLC $\mathrm{t}_{\mathrm{R}}: 13.8$ min. Purity: $>99 \%$. [Lu III $]$-DOTA-PESIN (calculated MW): 1745.76; MALDI, m/z (\%): 1745.8 (100, $\left.[\mathrm{M}+\mathrm{H}]^{+}\right), 1767.7\left(10,[\mathrm{M}+\mathrm{Na}]^{+}\right)$; HPLC $\mathrm{t}_{\mathrm{R}}: 14.1 \mathrm{~min}$. Purity: $>99 \%$.

Preparation of radiotracer for in vitro and in vivo studies

$\left[{ }^{177} \mathrm{Lu}\right]$-DOTA-PESIN was prepared by dissolving $10 \mu \mathrm{g}$ of the peptide $(6.35 \mathrm{nmol})$ in ammonium acetate buffer (300 $\mu \mathrm{l}, 0.5 \mathrm{~mol} / \mathrm{l}, \mathrm{pH} 5.5$ ); after addition of ${ }^{177} \mathrm{LuCl}_{3}$ $\left(2 \mathrm{mCi}\right.$ ), the solution was incubated for $15 \mathrm{~min}$ at $95^{\circ} \mathrm{C}$. A 1.5 molar excess of $\mathrm{Lu}\left(\mathrm{NO}_{3}\right)_{3} \cdot 5 \mathrm{H}_{2} \mathrm{O}$ was added and incubated again for $15 \mathrm{~min}$. Subsequently, $\left[{ }^{177} \mathrm{Lu}\right]-D O T A-$ PESIN was purified utilising a SepPak $\mathrm{C}_{18}$ cartridge preconditioned with $10 \mathrm{ml}$ methanol and $10 \mathrm{ml}$ water; the cartridge was eluted with $3 \mathrm{ml}$ water, followed by $2 \mathrm{ml}$ ethanol to yield pure $\left[{ }^{177} \mathrm{Lu}\right]$-DOTA-PESIN. For biodistribution studies, the labelling was performed accordingly without the addition of cold $\mathrm{Lu}\left(\mathrm{NO}_{3}\right)_{3} \cdot 5 \mathrm{H}_{2} \mathrm{O}$. Oxidation of C-terminal $\mathrm{MetNH}_{2}$ was suppressed by the addition of methionine. The solution for injection was prepared by dilution with $0.9 \%$ $\mathrm{NaCl}(0.1 \%$ BSA $)$ to provide the radioligand solution. $\left[{ }^{67} \mathrm{Ga}\right]$-DOTA-PESIN was prepared in the same way. All radiolabelled peptides were analysed with analytical HPLC and showed a radiochemical purity of $>97 \%$.

\section{Preparation of $\left[{ }^{68} \mathrm{Ga}\right]$-DOTA-PESIN for PET imaging}

The generator eluate containing $\sim 0.5 \mathrm{GBq}{ }^{68} \mathrm{Ga}$ in $0.2 \mathrm{ml} /$ $0.5 \mathrm{~mol} / 1 \mathrm{HCl}$ was evaporated to dryness and redissolved in $0.2 \mathrm{ml}$ acetate buffer $(\mathrm{pH} 4.8,0.1 \mathrm{~mol} / \mathrm{l})$. After addition of $5 \mu 1$ of a $1 \mathrm{mmol} / 1$ aqueous DOTA-PESIN solution, the mixture was kept for $10 \mathrm{~min}$ at $90^{\circ} \mathrm{C}$. The uncomplexed ${ }^{68} \mathrm{Ga}$ was separated by adsorption onto a SepPak $\mathrm{C}_{18}$ cartridge that was equilibrated with $0.1 \mathrm{~mol} / \mathrm{l}$ acetate buffer (pH 6.2), whereas $\left[{ }^{68} \mathrm{Ga}\right]$-DOTA-PESIN was eluted with $1.5 \mathrm{ml}$ ethanol. After evaporation of the organic solvent, the radiotracer was redissolved in $0.01 \mathrm{~mol} / 1$ phosphate-buffered saline ( $\mathrm{pH}$ 7.4) containing $0.5 \mathrm{mg} / \mathrm{ml}$ human serum albumin. The preparations were checked for bound and free ${ }^{68} \mathrm{Ga}$ by paper chromatography using Whatman No.1 and methanol $/ 0.01 \mathrm{~mol} / 1$ acetate buffer $(\mathrm{pH} 6.2)$ at a ratio of 55:45. ${ }^{68} \mathrm{Ge}$ contamination of the $\left[{ }^{68} \mathrm{Ga}\right]$-DOTA-PESIN preparation was determined by gamma counting after a decay period of $\geq 30 \mathrm{~h}$.

Binding affinity and receptor subtype profile

Using $\left[{ }^{125} \mathrm{I}-\mathrm{D}-\mathrm{Tyr}{ }^{4}\right] \mathrm{BN}$ as a GRP-R preferring ligand, the $\mathrm{IC}_{50}$ values of $\left[{ }^{\text {nat }} \mathrm{Ga} /{ }^{\text {nat }} \mathrm{Lu}\right]$-DOTA-PESIN were measured in competitive binding experiments performed with increasing concentrations of ${ }^{\text {nat }} \mathrm{Ga} /{ }^{\text {nat }} \mathrm{Lu}$-labelled peptides in successive tissue sections containing tumours expressing GRP-R [29].

The binding affinity profile for the three $\mathrm{BN}$ receptor subtypes was determined as described in detail previously $[11,30]$. Human tumours were selected that have previously been shown to express predominantly one single BN receptor subtype. $\mathrm{IC}_{50}$ values were determined in competitive binding experiments performed with increasing amounts of ${ }^{\text {nat }} \mathrm{Ga} /{ }^{\text {nat }}$ Lu-DOTA-PESIN using $\left[{ }^{125} \mathrm{I}-\mathrm{D}-\mathrm{Tyr}{ }^{6}\right.$, $\left.\beta-\mathrm{Ala}^{11}, \mathrm{Phe}^{13}, \mathrm{Nle}^{14}\right] \mathrm{BN}(6-14)$ as universal radioligand.

Cell culture

PC-3 cells (ECACC, Wiltshire SP4 OJG, UK) were cultured in DMEM. DMEM was supplemented with vitamins, 
essential and non-essential amino acids, L-glutamine, antibiotics (penicillin/streptomycin), fungicide [amphotericin B (Fungizone)] and 10\% FCS.

\section{Internalisation and efflux studies}

Internalisation and externalisation experiments were performed in six-well plates as described previously [17]. Briefly, approximately $3 \mathrm{kBq}(0.25 \mathrm{pmol})$ of $\left[{ }^{177} \mathrm{Lu} /{ }^{67} \mathrm{Ga}\right]$ DOTA-PESIN was added to PC-3 cell-containing incubation medium $\left(0.5-1 \times 10^{6}\right.$ cells per well $)$ and incubated at $37^{\circ} \mathrm{C}$ in a $5 \% \mathrm{CO}_{2}$ environment at different time points $(0.5,1,2,4$ and $6 \mathrm{~h})$. A large excess of [ $\left[\mathrm{Ga}^{\mathrm{III}}\right]$-DOTAPESIN $(0.4 \mu \mathrm{mol} / 1,150 \mu \mathrm{l})$ was used to determine non-specific internalisation. At each time point, the internalisation was stopped by removal of the medium followed by washing the cells with ice-cold solution composed of $0.9 \%$ $\mathrm{NaCl} / 0.01 \mathrm{~mol} / 1 \mathrm{Na}_{2} \mathrm{HPO}_{4} / 0.01 \mathrm{~mol} / 1 \mathrm{KH}_{2} \mathrm{PO}_{4}(\mathrm{pH} 7.2$ ). Cells were then treated (twice) with glycine buffer $(0.05 \mathrm{~mol} / \mathrm{l}$ glycine solution, $\mathrm{pH}$ adjusted to 2.8 with $1 \mathrm{~mol} / \mathrm{l} \mathrm{HCl}$ ) for $5 \mathrm{~min}$ to distinguish between cell surface-bound (acid buffer removable) and internalised (acid-resistant) radioligand. Finally, cells were detached from the plates by incubation with $1 \mathrm{~mol} / \mathrm{l} \mathrm{NaOH}$ for $10 \mathrm{~min}$ at $37^{\circ} \mathrm{C}$, and the radioactivity was measured in a gamma counter. The percentage of added activity per million cells ( $\%$ of total) was calculated for internalisation at each time point.

For externalisation studies, PC-3 cells were allowed to internalise $\left[{ }^{177} \mathrm{Lu} /{ }^{67} \mathrm{Ga}\right.$ ]-DOTA-PESIN for $2 \mathrm{~h}$; they were then exposed to an acid wash, as described in the internalisation experiments, to dissociate the cell surface-bound radioligand. Then $1 \mathrm{ml}$ of culture medium (1\% FCS) was added to each well, the cells were incubated at $37^{\circ} \mathrm{C}$ in a $5 \% \mathrm{CO}_{2}$ environment and the externalisation of the cellincorporated radioactivity was studied at different times. The culture medium was collected and measured for radioactivity. The percentage of total internalised radiotracer was calculated for efflux.

\section{Biodistribution experiments in PC-3 tumour-bearing} nude mice

After a slight anaesthesia with isoflurane in an air/oxygen mixture, athymic nude female mice (Harlan, the Netherlands) were implanted subcutaneously on the right flank with about 10 million PC-3 tumour cells, which were freshly expanded in $100 \mu \mathrm{l}$ sterilised PBS solution.

Seven to ten days after inoculation the tumours weighed $60-130 \mathrm{mg}$ and the mice were injected via the tail vein with 10 pmol radiolabelled peptide (about $0.12 \mathrm{MBq}\left[{ }^{67} \mathrm{Ga}\right]-$ DOTA-PESIN), diluted in $0.9 \% \mathrm{NaCl}(0.1 \% \mathrm{BSA}$, pH 7.4 , total injected volume $100 \mu \mathrm{l}$ ). For the determination of non- specific uptake in the tumour and receptor-positive organs, a group of four animals was injected with a mixture of 10 pmol radiolabelled peptide $/ 50 \mu \mathrm{g}\left[\mathrm{Ga}^{\mathrm{III}}\right]$-DOTA-PESIN in $0.9 \% \mathrm{NaCl}$ solution (injected volume, $150 \mu \mathrm{l}$ ). To study the biodistribution of $\left[{ }^{67} \mathrm{Ga}\right]$-DOTA-PESIN, mice were sacrificed at 1, 4 and $24 \mathrm{~h}$ post injection; the organs of interest were collected, rinsed of excess blood, blotted, weighed and counted in a $\gamma$-counter. The percentage of injected activity per gram $(\% \mathrm{IA} / \mathrm{g})$ was calculated for each tissue. The total counts injected per animal were determined by extrapolation from counts of an aliquot taken from the injected solution as a standard. For the biodistribution study of $\left[{ }^{177} \mathrm{Lu}\right]$-DOTA-PESIN, mice were sacrificed at 4, 24, 48 and $72 \mathrm{~h}$ post injection.

To study the influence of lysine, $15 \mathrm{mg}$ lysine was coinjected with $10 \mathrm{pmol}\left[{ }^{67} \mathrm{Ga}\right]$-DOTA-PESIN in $150 \mu \mathrm{l}$, and the animals were sacrificed at $4 \mathrm{~h}$ post injection.

Biodistribution studies with $\left[{ }^{67} \mathrm{Ga}\right]$-DOTA-PESIN were also performed at the German Cancer Research Centre under conditions of PET imaging with $\left[{ }^{68} \mathrm{Ga}\right]$-DOTAPESIN. Six- to 8-week-old female Swiss CD1 nu/nu mice were inoculated with a PC-3 tumour in the right flank. Eleven to thirteen days later, tumours weighing $70-175 \mathrm{mg}$ were ready for experiment. Fifteen pmol $(0.61 \mathrm{MBq})$ $\left[{ }^{67} \mathrm{Ga}\right]$-DOTA-PESIN was injected into the lateral tail vein. Mice were sacrificed at $1 \mathrm{~h}$ p.i. and organs of interest collected for measurement as described previously [31].

\section{PET imaging with $\left[{ }^{68} \mathrm{Ga}\right]$-DOTA-PESIN}

PET imaging was performed on a Siemens ECAT EXACT $\mathrm{HR}^{+}$scanner (Siemens/CTI, Knoxville, TN, USA), and PET data were acquired in $3 \mathrm{D}$ mode and reconstructed iteratively with a full $3 \mathrm{D}$ algorithm from a $256 \times 256$ matrix for viewing transaxial, coronal and sagittal slices of $0.57 \mathrm{~mm}$ thickness. Pixel size was $1.14 \mathrm{~mm}$ and transaxial resolution obtained was $2.8 \mathrm{~mm}$. For imaging studies, an awake female CD1 nu/nu mouse that was inoculated with a PC-3 tumour on the right flank was lightly restrained and injected with $1.94 \mathrm{MBq}, 15 \mathrm{pmol}\left[{ }^{68} \mathrm{Ga}\right]$-DOTA-PESIN via a lateral tail vein. One hour later the mouse was anaesthetised with isoflurane in an air/oxygen mixture and sacrificed, then positioned in the tomograph symmetrically in the centre of the field of view. Acquisition of PET data was obtained with a 30-min emission and a 10-min transmission scan.

\section{Scintigraphy with $\left[{ }^{177}\right.$ Lu]-DOTA-PESIN}

Scintigraphic imaging of PC-3 tumour xenografts was performed on a PRISM 2000 XP camera. Two mice were inoculated with a PC-3 tumour on the right hind leg. After 16 days the tumours had grown enough for imaging. Both 
animals were lightly restrained and injected with $13.5 \mathrm{MBq}$, $0.32 \mathrm{nmol}\left[{ }^{177} \mathrm{Lu}\right]-D O T A-P E S I N$ via a lateral tail vein; one of them was co-injected with $50 \mu \mathrm{g}\left[\mathrm{Ga}^{\mathrm{III}}\right]$-DOTA-PESIN. Four hours after injection, the animals were anaesthetised with isoflurane in an air/oxygen mixture and positioned on the head of the camera symmetrically in the centre of the field of view while anaesthesia was monitored by observing the breath frequency. Scans were taken $15 \mathrm{~min}$ after anaesthesia at 4, 24, 48 and $72 \mathrm{~h}$ post injection.

All animal experiments were performed in compliance with the Swiss regulations for animal treatment (Bundesamt für Veterinärwesen, approval no. 789), or with the German laws for the protection of animals.

Statistical analysis

Data are expressed as mean $\pm \mathrm{SD}$, which were calculated on Microsoft Excel. Student's $t$ test (Origin 6, Microcal Software, Inc., Northampton, MA) was used to determine statistical significance at the $95 \%$ confidence level with $p<0.05$ being considered significantly different.

\section{Results}

Synthesis and radiolabelling

DOTA-PESIN (Fig. 1) was synthesised using Fmoc strategy, affording yields of $45 \%$ based on the removal of the first Fmoc group; the purity analysed by HPLC was $\geq 97 \%$. DOTA-PESIN and $\left[\mathrm{Ga}^{\mathrm{III}} / \mathrm{Lu}^{\mathrm{III}}\right]$-DOTA-PESIN were characterised by electrospray and MALDI TOFF mass spectrometry. Radiolabelled DOTA-PESIN was prepared by incubation with ${ }^{67 / 68} \mathrm{GaCl}_{3}$ or ${ }^{177} \mathrm{LuCl}_{3}$ at elevated temperature. The labelling yield of $\left[{ }^{67 / 68} \mathrm{Ga}\right]$-DOTA-PESIN was $\geq 98 \%$ at specific activities of $>129 \mathrm{GBq} \mu \mathrm{mol}^{-1}$ for ${ }^{68} \mathrm{Ga}$ and $>12 \mathrm{GBq} \mu \mathrm{mol}^{-1}$ for ${ }^{67} \mathrm{Ga}$, respectively. The radiolytic oxidation of methionine in $\left[{ }^{177} \mathrm{Lu}\right]$-DOTA-PESIN was about $2 \%$ when the specific activity was $\leq 11.6 \mathrm{GBq} \mu \mathrm{mol}^{-1}$ and reached $26 \%$ at $60 \mathrm{GBq} \mu \mathrm{mol}^{-1}$. With optimisation of the labelling conditions, labelling yields of $\geq 95 \%$ of $\left[{ }^{177} \mathrm{Lu}\right]$-DOTA-PESIN were achieved at a specific activity of $>85 \mathrm{GBq} \mu \mathrm{mol}^{-1}$ in the presence of $400 \mu \mathrm{g}$ methionine per $370 \mathrm{MBq}{ }^{177} \mathrm{Lu}$.
Receptor binding affinity and profile

Table 1 shows the GRP-R binding affinities of DOTAPESIN and its respective metallopeptides to human cancer tissue overexpressing GRP-R, as determined by a competitive binding assay using $\left[{ }^{125} \mathrm{I}-\mathrm{Tyr}^{4}\right] \mathrm{BN}$ as radioligand. On the human GRP-R, the $\mathrm{IC}_{50}$ values were $9.5 \pm 3.4 \mathrm{nmol} / 1$ for DOTA-PESIN and $6.1 \pm 3.0 \mathrm{nmol} / 1$ and $6.6 \pm 0.1 \mathrm{nmol} / 1$ for the $\mathrm{Lu}^{\mathrm{III}}$ - and $\mathrm{Ga}^{\mathrm{III}}$-complexed peptides, respectively. There was no significant difference on the mouse GRP-R.

$\left[\mathrm{Ga}^{\mathrm{III}}\right]$-DOTA-PESIN and $\left[\mathrm{Lu}^{\mathrm{II}}\right]$-DOTA-PESIN were also studied with respect to the $\mathrm{BN}$ receptor subtype profile using human cancer tissue shown to express predominantly a single $\mathrm{BN}$ receptor subtype. Using $\left[{ }^{125} \mathrm{I}-\mathrm{D}-\mathrm{Tyr}^{6}, \beta-\mathrm{Ala}^{11}\right.$, $\left.\mathrm{Phe}^{13}, \mathrm{Nle}^{14}\right] \mathrm{BN}(6-14)$ as radioligand, the binding studies showed good binding affinities to NMB-R and GRP-R, and no affinity to BB3-R.

Internalisation and efflux studies

Internalisation of both radiopeptides was followed for $6 \mathrm{~h}$. Both ${ }^{177} \mathrm{Lu}$ - and ${ }^{67} \mathrm{Ga}$-labelled DOTA-PESIN showed specific and time-dependent cell uptake, reaching $39.1 \pm$ $1.1 \%$ and $43.7 \pm 1.8 \%$ of the total amount added to the medium, respectively, after $6 \mathrm{~h}$ of incubation at $37^{\circ} \mathrm{C}$ (Fig. 2). Within the first $2 \mathrm{~h}$ of incubation $\left[{ }^{177} \mathrm{Lu}\right]-D O T A-$ PESIN internalised somewhat faster than $\left[{ }^{67} \mathrm{Ga}\right]$-DOTAPESIN but after $4 \mathrm{~h}$ there was no statistical difference. The efflux kinetics (Fig. 3) showed a cellular retention of $52.5 \pm$ $1.6 \%$ of the total internalised activity $20 \mathrm{~h}$ after start of efflux for both radiopeptides.

\section{Animal biodistribution studies}

Biodistribution studies using the ${ }^{67} \mathrm{Ga} /{ }^{177} \mathrm{Lu}$-labelled peptides were performed with athymic nude female mice bearing the PC-3 human prostate tumour; the results are presented in Tables 2 and 3 as percentage of injected activity per gram of tissue $(\% \mathrm{IA} / \mathrm{g})$.

According to Table 2, $\left[{ }^{67} \mathrm{Ga}\right]$-DOTA-PESIN and $\left[{ }^{177} \mathrm{Lu}\right]-$ DOTA-PESIN (data in parentheses in the following) displayed rapid blood clearance from the PC-3-bearing mice, with $0.47 \pm 0.06 \% \mathrm{IA} / \mathrm{g}$ at $1 \mathrm{~h}$ and $0.11 \pm 0.04(0.04 \pm$ $0.01) \% \mathrm{IA} / \mathrm{g}$ at $4 \mathrm{~h}$ post injection. Both radiotracers were
Fig. 1 Structural formula of DOTA-PESIN

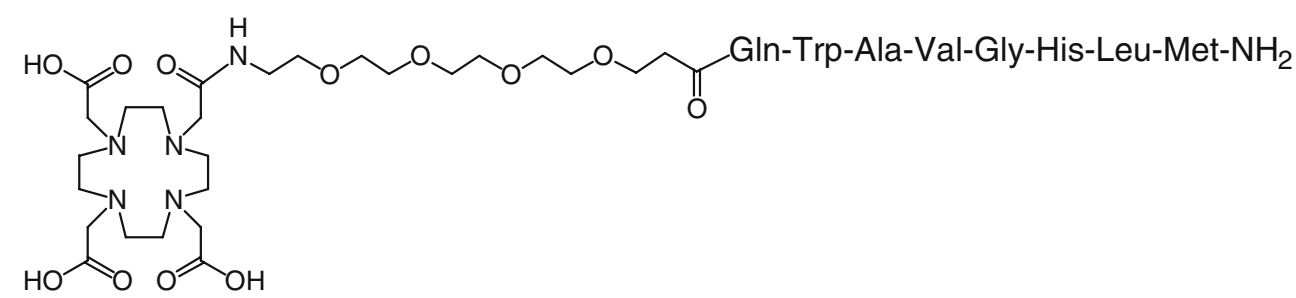


Table $1 \mathrm{IC}_{50}$ values for metallated DOTA-PESIN when competed with $\left[{ }^{125} \mathrm{I}-\mathrm{Tyr}^{4}\right] \mathrm{BN}$ against the human and mouse GRP-R and affinity profiles using $\left[{ }^{125} \mathrm{I}^{-\mathrm{Tyr}^{6}}, \beta-\mathrm{Ala}^{11}, \mathrm{Phe}^{13}, \mathrm{Nle}^{14}\right] \mathrm{BN}(6-14)$

\begin{tabular}{llllll}
\hline Compound & Human GRP-R & Mouse GRP-R & & \multicolumn{2}{l}{ BN receptor subtypes } \\
\cline { 5 - 6 } & & & NMB-R & GRP-R & BB3-R \\
\hline DOTA-PESIN & $9.5 \pm 3.4(3)$ & ND & ND & ND & ND \\
{$\left[\mathrm{Lu}^{\text {III }}\right]$-DOTA-PESIN } & $6.1 \pm 3.0(3)$ & ND & $15.0 \pm 4.0(2)$ & $8.3 \pm 1.7(2)$ & $>1,000(2)$ \\
{$\left[\mathrm{Ga}^{\text {III }}\right]$-DOTA-PESIN } & $6.6 \pm 0.1(3)$ & $7.0 \pm 1.2(3)$ & $12.5 \pm 0.5(2)$ & $10.0 \pm 0.0(2)$ & $>1,000(2)$ \\
\hline
\end{tabular}

$\mathrm{IC}_{50}$ values $(\mathrm{nmol} / \mathrm{l} \pm \mathrm{SE})$ are in triplicates. Numbers of independent studies are listed in parentheses

$N D$ not determined

quickly washed out from the GRP-R-negative tissues except the kidneys. $\left[{ }^{67} \mathrm{Ga} /{ }^{177} \mathrm{Lu}\right]$-DOTA-PESIN also showed high uptake in the human prostate tumour xenograft and in the mouse GRP-R-positive organs, e.g. at $4 \mathrm{~h}$ the tumour uptake was $8.77 \pm 1.88(7.46 \pm 1.64) \% \mathrm{IA} / \mathrm{g}$ and the pancreas uptake $43.8 \pm 6.9(39.0 \pm 4.9) \% \mathrm{IA} / \mathrm{g}$. In vivo competition experiments (Table 2) involving coinjection of $50 \mu \mathrm{g}\left[\mathrm{Ga}^{\mathrm{III}}\right]$-DOTA-PESIN with $\left[{ }^{67} \mathrm{Ga}\right]-$ DOTA-PESIN resulted in a $>94 \%$ reduction of uptake in the tumour and also in a reduction of uptake in other GRPR-positive organs, e.g. $>95 \%$ in the pancreas and $97 \%$ in the pituitary, $83-85 \%$ in the adrenals, spleen and bowel, and $78 \%$ in the stomach, showing specific receptormediated uptake in these tissues. The injection of the blocking dose had no significant influence on the uptake in other non-target organs whereas it led to a somewhat decreased kidney uptake. Co-injection of lysine did not reduce the kidney uptake, and the ratio between tumour and kidney remained almost unchanged. The impact of the blocking dose on biodistribution of $\left[{ }^{177} \mathrm{Lu}\right]$-DOTA-PESIN can be seen from the scans shown in Fig. 6.

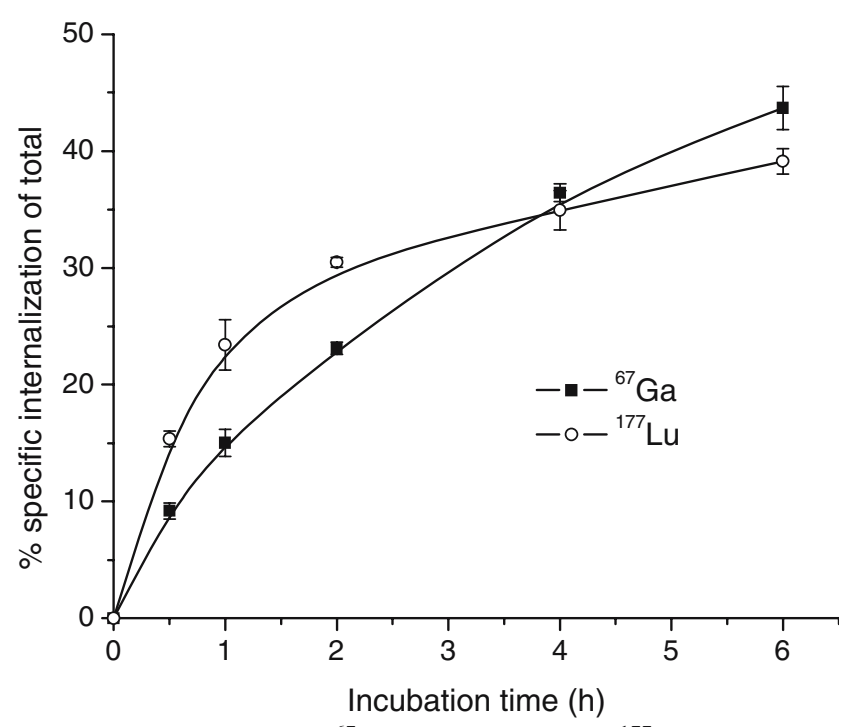

Fig. 2 Internalisation of ${ }^{67}$ Ga-labelled (匹) and ${ }^{177}$ Lu-labelled (o) DOTA-PESIN into PC-3 cells. Data are from two independent experiments with triplicates in each experiment and are expressed as $\%$ specific internalisation of total activity added to the medium
Due to the rapid clearance from the body, high tumourto-background ratios were found (Table 3). These ratios increased with time. For instance, the ratios of $\left[{ }^{67} \mathrm{Ga}\right]$ DOTA-PESIN between tumour and blood (muscle) varied from 31 (62) to 211 (237) during $1 \mathrm{~h}$ to $24 \mathrm{~h}$ post injection; for $\left[{ }^{177} \mathrm{Lu}\right]$-DOTA-PESIN, the respective ratios were 201 (147) at $4 \mathrm{~h}, 215$ (387) at $24 \mathrm{~h}$ and 715 (486) at $72 \mathrm{~h}$ post injection. Both radiotracers also displayed high tumour-tokidney and tumour-to-liver ratios (in parentheses): 2.4-2.6 (22-23) for the ${ }^{67} \mathrm{Ga}$-labelled and 1.7-3.6 (36-52) for the ${ }^{177}$ Lu-labelled peptide.

The pharmacokinetics (Fig. 4) of $\left[{ }^{67} \mathrm{Ga}\right]$-DOTA-PESIN shows the potential to visualise the tumour very early owing to the high initial accumulation, which reached $14.8 \pm 2.4 \%$ $\mathrm{IA} / \mathrm{g}$ at $1 \mathrm{~h}$ p.i. $(9.40 \pm 1.39 \% \mathrm{IA} / \mathrm{g}$ with an injected dose of 15 pmol and a different mouse strain), decreased to $8.77 \pm$ $1.88 \% \mathrm{IA} / \mathrm{g}$ at $4 \mathrm{~h}$ and was still $6.76 \pm 0.29 \% \mathrm{IA} / \mathrm{g}$ at $24 \mathrm{~h}$. $\left[{ }^{177} \mathrm{Lu}\right]$-DOTA-PESIN also displayed a high uptake in the tumour and a relatively slow washout: $7.46 \pm 1.64 \% \mathrm{IA} / \mathrm{g}$ at $4 \mathrm{~h}, 5.81 \pm 0.40 \% \mathrm{IA} / \mathrm{g}$ at $24 \mathrm{~h}, 4.05 \pm 0.23 \% \mathrm{IA} / \mathrm{g}$ at

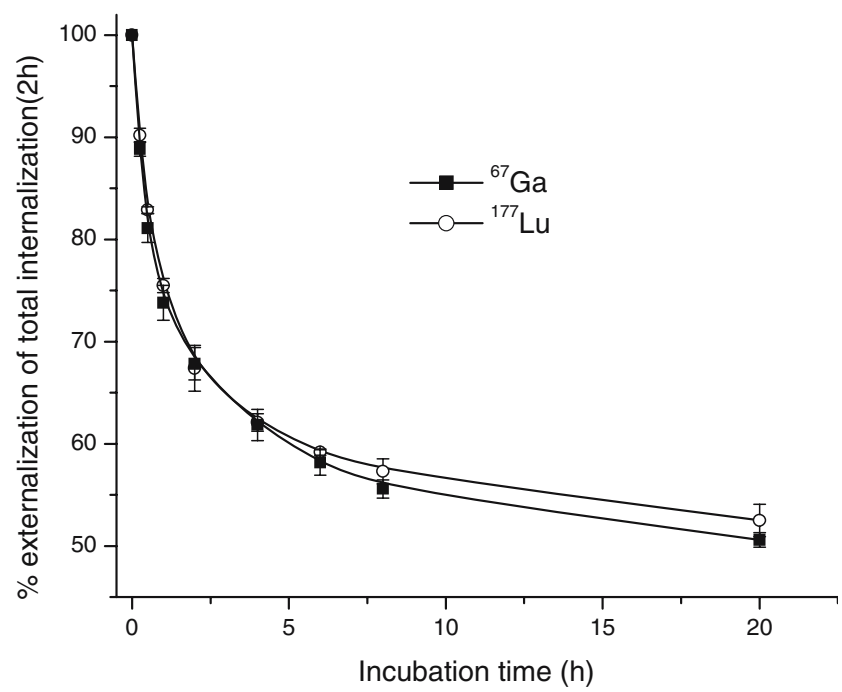

Fig. 3 Externalisation of ${ }^{67} \mathrm{Ga}$-labelled (ם) and ${ }^{177}$ Lu-labelled (०) DOTA-PESIN from PC-3 cells. Cells were allowed to internalise for $2 \mathrm{~h}$. Data are from two independent experiments with triplicates in each experiment and are expressed as \% specifically externalised of total activity internalised added to the medium 
Table 2 Biodistribution analysis (\%IA/g $\pm \mathrm{SD})$ of ${ }^{67} \mathrm{Ga}$ and ${ }^{177} \mathrm{Lu}$-labelled DOTA-PESIN in PC-3 tumour-bearing nude mice

\begin{tabular}{|c|c|c|c|c|c|c|}
\hline \multirow[t]{2}{*}{ Site } & \multirow{2}{*}{$\begin{array}{l}{ }^{67} \mathrm{Ga}^{\mathrm{a}} \\
1 \mathrm{~h}\end{array}$} & \multicolumn{4}{|l|}{${ }^{67} \mathrm{Ga}^{\mathrm{b}}$} & \multirow{2}{*}{$\begin{array}{l}{ }^{177} \mathrm{Lu}^{\mathrm{b}} \\
4 \mathrm{~h}\end{array}$} \\
\hline & & $1 \mathrm{~h}$ & $4 \mathrm{~h}$ & 4 h blocked $^{\mathrm{c}}$ & 4 h lysine ${ }^{\mathrm{d}}$ & \\
\hline Blood & $0.556 \pm 0.120$ & $0.471 \pm 0.060$ & $0.108 \pm 0.041$ & $0.103 \pm 0.029$ & $0.235 \pm 0.012$ & $0.037 \pm 0.011$ \\
\hline Muscle & $0.160 \pm 0.046$ & $0.243 \pm 0.170$ & $0.042 \pm 0.008$ & $0.043 \pm 0.004$ & $0.068 \pm 0.014$ & $0.051 \pm 0.015$ \\
\hline Adrenals & $\mathrm{NC}$ & $20.6 \pm 2.1$ & $15.8 \pm 3.2$ & $2.80 \pm 2.59$ & $16.1 \pm 2.4$ & $15.3 \pm 3.4$ \\
\hline Pancreas & $47.7 \pm 4.7$ & $65.3 \pm 8.7$ & $43.8 \pm 6.9$ & $2.26 \pm 2.00$ & $54.8 \pm 8.3$ & $39.0 \pm 4.9$ \\
\hline Spleen & $2.62 \pm 0.28$ & $2.67 \pm 0.47$ & $2.25 \pm 0.16$ & $0.48 \pm 0.05$ & $2.36 \pm 0.10$ & $2.55 \pm 0.55$ \\
\hline Kidney & $4.27 \pm 0.66$ & $6.27 \pm 0.94$ & $3.36 \pm 0.47$ & $2.09 \pm 0.27$ & $4.67 \pm 0.97$ & $4.67 \pm 0.78$ \\
\hline Stomach & $\mathrm{NC}$ & $4.77 \pm 0.65$ & $1.72 \pm 0.86$ & $0.39 \pm 0.28$ & $2.39 \pm 0.21$ & $1.68 \pm 0.43$ \\
\hline Bowel & $7.23 \pm 0.66$ & $7.41 \pm 0.79$ & $3.65 \pm 1.55$ & $0.57 \pm 0.47$ & $5.75 \pm 1.21$ & $3.77 \pm 1.30$ \\
\hline Liver & $0.50 \pm 0.10$ & $0.64 \pm 0.15$ & $0.41 \pm 0.06$ & $0.44 \pm 0.15$ & $0.37 \pm 0.03$ & $0.21 \pm 0.04$ \\
\hline Lung & $0.60 \pm 0.12$ & $0.69 \pm 0.16$ & $0.41 \pm 0.16$ & $0.19 \pm 0.05$ & $0.22 \pm 0.03$ & $0.10 \pm 0.04$ \\
\hline Heart & $\mathrm{NC}$ & $0.31 \pm 0.08$ & $0.06 \pm 0.01$ & $0.06 \pm 0.01$ & $0.12 \pm 0.01$ & $0.06 \pm 0.01$ \\
\hline Bone & $0.35 \pm 0.06$ & $0.60 \pm 0.20$ & $0.40 \pm 0.14$ & $0.22 \pm 0.10$ & $0.62 \pm 0.07$ & $0.48 \pm 0.06$ \\
\hline Pituitary & $\mathrm{NC}$ & $18.7 \pm 9.8$ & $3.35 \pm 1.62$ & $0.09 \pm 0.08$ & $3.07 \pm 0.77$ & $3.44 \pm 0.53$ \\
\hline Tumour & $9.40 \pm 1.39$ & $14.8 \pm 2.5$ & $8.77 \pm 1.88$ & $0.52 \pm 0.21$ & $8.87 \pm 1.1$ & $7.46 \pm 1.63$ \\
\hline
\end{tabular}

Results are the mean of groups of four to eight mice

$N C$ not collected

${ }^{a}$ PC-3 tumour-bearing CD nude mice were used for the biodistribution of 15 pmol $(0.61 \mathrm{MBq})\left[{ }^{67} \mathrm{Ga}\right]-\mathrm{DOTA}-\mathrm{PESIN}$

${ }^{\mathrm{b}} 10 \mathrm{pmol}\left[{ }^{67} \mathrm{Ga} /{ }^{177} \mathrm{Lu}\right]-D O T A-P E S I N$ was injected to PC-3 tumour-bearing athymic nude mice

${ }^{\mathrm{c}}$ Blocked by co-injection of $50 \mu \mathrm{g}\left[\mathrm{Ga}^{\mathrm{III}}\right]$-DOTA-PESIN

${ }^{\mathrm{d}}$ Co-injection of $15 \mathrm{mg}$ lysine per mouse

$48 \mathrm{~h}$ and $2.43 \pm 0.12 \% \mathrm{IA} / \mathrm{g}$ at $72 \mathrm{~h}$. In the pancreas, $\left[{ }^{177} \mathrm{Lu}\right]$-DOTA-PESIN was released faster than the ${ }^{67} \mathrm{Ga}$ labelled peptide. In addition, the release of $\left[{ }^{177} \mathrm{Lu}\right]$-DOTAPESIN from the pancreas and kidneys was faster than from the tumour, leading to an increasing tumour-to-organ ratio with time.

\section{PET imaging}

Iteratively reconstructed PET images of PC-3 tumour xenografts with $\left[{ }^{68} \mathrm{Ga}\right]$-DOTA-PESIN (1.94 MBq, 15 pmol) were performed at $1 \mathrm{~h}$ post injection (Fig. 5). The PC-3 tumour was located in the thoracic wall, and was perceptible with clear contrast from the adjacent background in the transaxial slices. Coronal slices distinctly show the tumour and kidneys. Sagittal slices demonstrate that $\left[{ }^{68} \mathrm{Ga}\right]$-DOTA-PESIN accumulates predomi- nantly in the PC-3 tumour, pancreas and kidneys. The results of direct tissue counting and of PET imaging were consistent.

\section{Scintigraphy}

Figure 6 shows the scintigraphic imaging of PC-3 tumour xenografts with $\left[{ }^{177} \mathrm{Lu}\right]$-DOTA-PESIN (left: unblocked; right: blocked with $50 \mu \mathrm{g}\left[\mathrm{Ga}^{\mathrm{III}}\right]$-DOTA-PESIN). Imaging was performed at 4, 24, 48 and $72 \mathrm{~h}$ after injection. In the blocked mouse the tumour could not be visualised and only the kidneys were visible, whereas the PC-3 tumour of the non-blocked mouse was visualised with clear contrast from the adjacent background at all time points. Prominent uptake was also observed in the pancreas and kidneys. The imaging kinetics showed that $\left[{ }^{177} \mathrm{Lu}\right]$-DOTA-PESIN was preferably retained in the tumour rather than in the
Table 3 Radioactivity ratios between PC-3 tumour and other organs of ${ }^{67} \mathrm{Ga}$ - and ${ }^{177} \mathrm{Lu}$-labelled DOTA-PESIN in PC-3 tumour-bearing female athymic nude mice $[8 \geq n \geq 4]$

Tumour-to-blocked tumour ratio $(4 \mathrm{~h})=16.9$

\begin{tabular}{|c|c|c|c|c|c|c|c|c|}
\hline \multirow[t]{2}{*}{ Time (h) } & \multicolumn{2}{|c|}{ Blood } & \multicolumn{2}{|c|}{ Muscle } & \multicolumn{2}{|c|}{ Kidney } & \multicolumn{2}{|l|}{ Liver } \\
\hline & ${ }^{67} \mathrm{Ga}$ & ${ }^{177} \mathrm{Lu}$ & ${ }^{67} \mathrm{Ga}$ & ${ }^{177} \mathrm{Lu}$ & ${ }^{67} \mathrm{Ga}$ & ${ }^{177} \mathrm{Lu}$ & ${ }^{67} \mathrm{Ga}$ & ${ }^{177} \mathrm{Lu}$ \\
\hline 1 & 31 & & 62 & & 2.4 & & 23 & \\
\hline 4 & 81 & 201 & 209 & 147 & 2.6 & 1.7 & 22 & 36 \\
\hline 24 & 211 & 215 & 237 & 387 & 2.4 & 2.5 & 23 & 43 \\
\hline 48 & & 476 & & 488 & & 3.1 & & 52 \\
\hline 72 & & 715 & & 486 & & 3.6 & & 48 \\
\hline
\end{tabular}



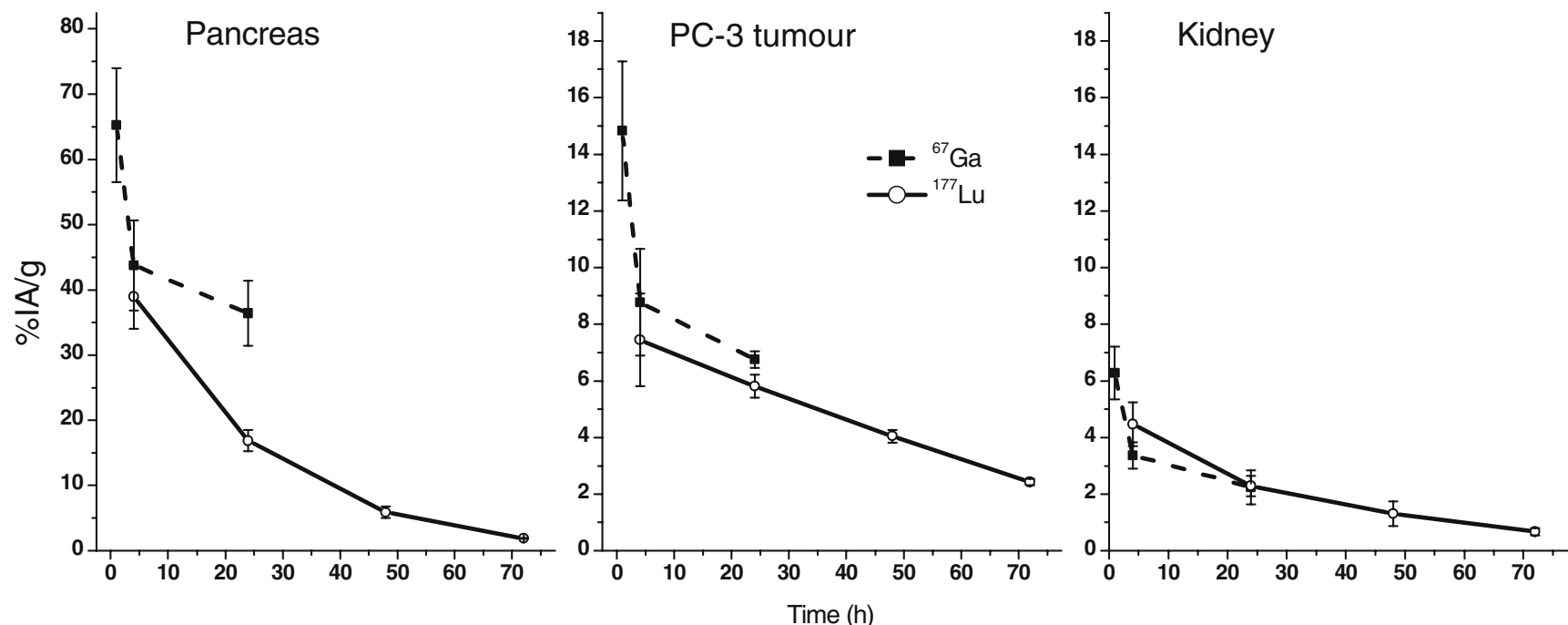

Fig. 4 Kinetics of ${ }^{67}$ Ga-labelled ( $\bullet$ ) and ${ }^{177}$ Lu-labelled (०) DOTA-PESIN in PC-3 tumour-bearing mice (left, pancreas; middle, PC-3 tumour; right, kidney)

pancreas and kidneys. These imaging results are consistent with biodistribution data (Fig. 4).

\section{Discussion}

We report on the development of a radiopeptide which can be used in SPECT $\left({ }^{67} \mathrm{Ga}\right)$, PET $\left({ }^{68} \mathrm{Ga}\right)$ and targeted radionuclide therapy $\left({ }^{177} \mathrm{Lu}\right)$ of $\mathrm{BN}$ receptor-positive tumours such as prostate and breast cancer or gastrointestinal stromal tumours. As part of a small library of peptides, which differ by the spacer between the chelate and the pharmacophoric peptide, DOTA-PEG 4 -BN(7-14) appeared to have promising properties in terms of a relatively high tumour-to-kidney and tumour-to-liver ratio. Therefore we decided to study this peptide in depth after labelling with
${ }^{67} \mathrm{Ga},{ }^{68} \mathrm{Ga}$ and ${ }^{177} \mathrm{Lu}$ with the aim of introducing these radiopeptides into the clinic. DOTA $(1,4,7,10$-tetraazacyclododecane-1,4,7,10-tetraacetic acid) was chosen as chelator since it forms $\mathrm{M}^{3+}$ complexes with high in vitro and in vivo stability [32]. $\mathrm{PEG}_{4}$ (15-amino-4,7,10,13-tetraoxapentadecanoic acid) was chosen as spacer and pharmacokinetic modifier. Very long PEG-based spacers $(>3,000$ D) coupled to peptides or antibodies appear to decrease the binding affinity of these biomolecules to their receptors and to lower the rate of internalisation significantly, as shown by Rogers et al. using a $\left[{ }^{64} \mathrm{Cu}\right]$-DOTA-PEG-BN (7-14) derivative [33]. Smaller versions do not seem to have a sufficient influence on the pharmacokinetics and hydrophilicity $[31,33]$.

The presented peptide was synthesised on solid phase with an overall yield of $>45 \% .{ }^{68} \mathrm{Ga}$ labelling was straight-
Fig. 5 Iteratively reconstructed PET images of PC-3 tumour xenograft with $\left[{ }^{68} \mathrm{Ga}\right]$-DOTAPESIN (1.94 MBq, 15 pmol) performed at $1 \mathrm{~h}$ post injection. The transaxial slice shows the PC-3 tumour (right flank) to be located in the thoracic wall. The coronal slice shows a clear distinction between tumour and kidneys. The sagittal slice demonstrates that $\left[{ }^{68} \mathrm{Ga}\right]-$ DOTA-PESIN accumulates predominantly in the PC-3 tumour, pancreas and kidneys

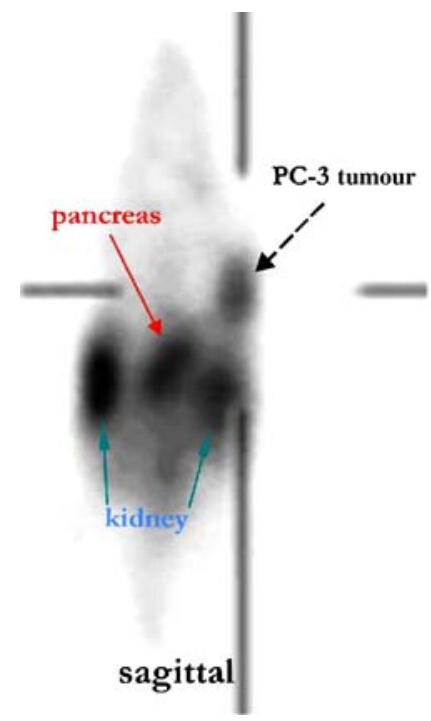

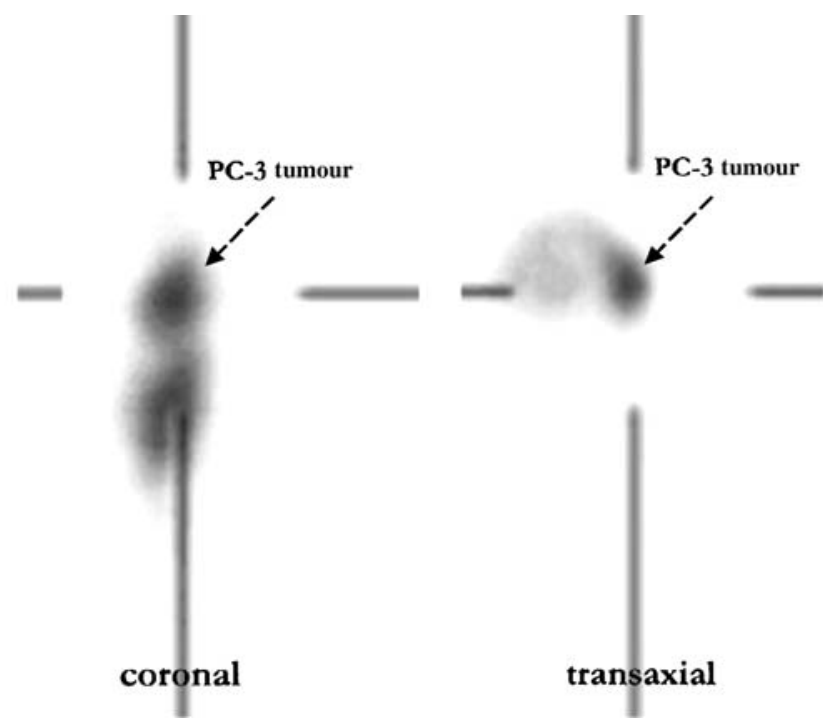


Fig. 6 Scintigraphic images of $\left[{ }^{177} \mathrm{Lu}\right]$-DOTA-PESIN in PC-3 tumour-bearing mice at $4,24,48$ and $72 \mathrm{~h}$ post injection (13.5 MBq, blocked with $50 \mu \mathrm{g}$ $\left[\mathrm{Ga}^{\mathrm{III}}\right]$-DOTA-PESIN. Left, unblocked; right, blocked)
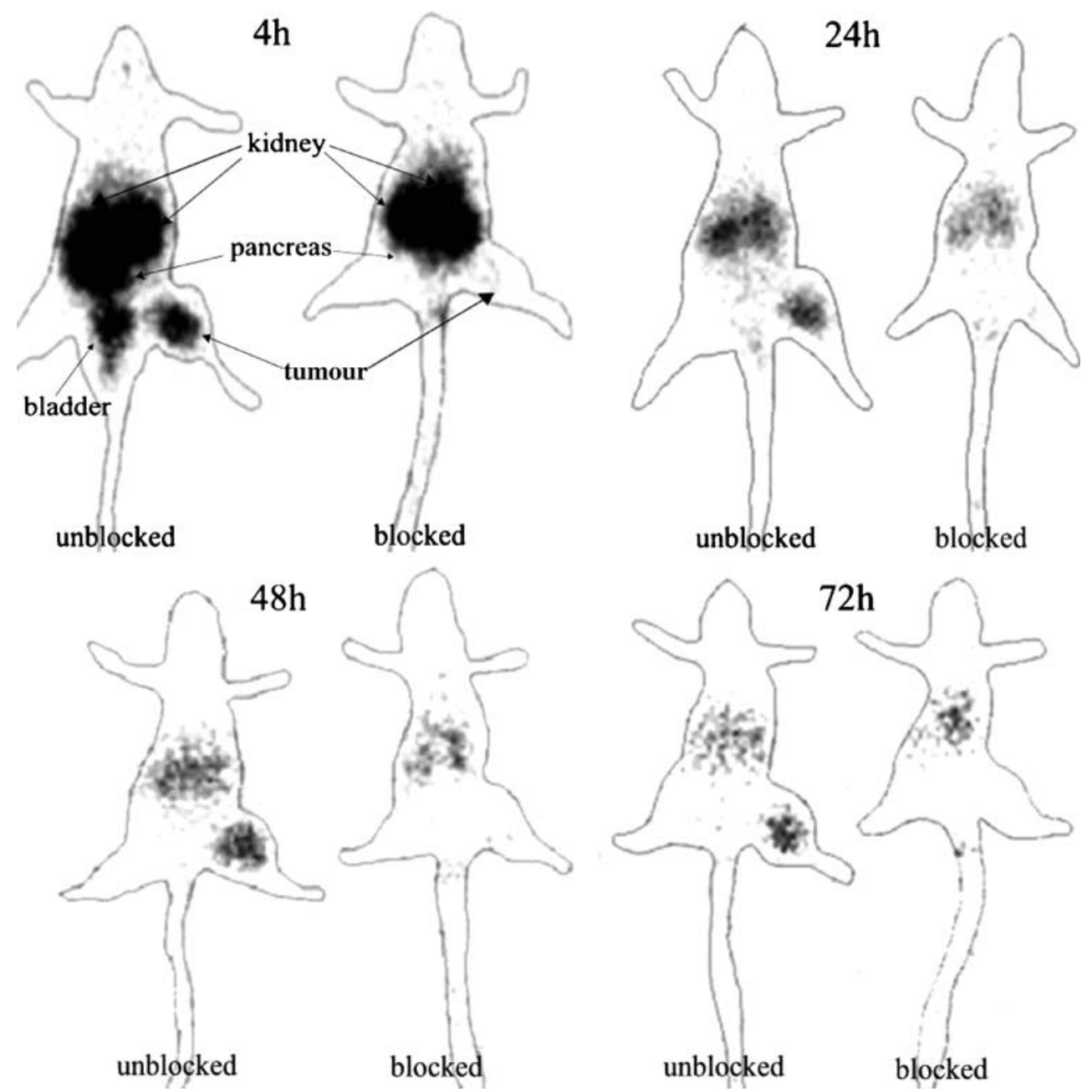

forward and afforded high radiochemical yields at a reasonable specific activity of $\geq 130 \mathrm{GBq}^{\mathrm{mmol}}{ }^{-1}$, which allowed production of good PET images at $1 \mathrm{~h}$ post injection. Sagittal slices clearly showed that $\left[{ }^{68} \mathrm{Ga}\right]-D O T A-$ PESIN mainly localises the PC-3 tumour, the GRP receptorpositive pancreas and the kidneys.

Binding studies using the GRP receptor ligand $\left[{ }^{125} \mathrm{I}-\right.$ $\left.\mathrm{Tyr}^{4}\right] \mathrm{BN}$ revealed medium affinity of $\left[\mathrm{Ga}^{\mathrm{III}}\right]$-DOTA-PESIN and $\left[\mathrm{Lu}^{\mathrm{III}}\right]$-DOTA-PESIN to the human GRP receptor and no difference between human and mouse GRP receptors, at least for $\left[\mathrm{Ga}^{\mathrm{III}}\right]-\mathrm{DOTA}-\mathrm{PESIN}$. The affinity to the three human $\mathrm{BN}$ receptor subtypes using the universal radioligand $\left[{ }^{125} \mathrm{I}-\mathrm{D}-\mathrm{Tyr}^{6}, \quad \beta\right.$-Ala $\left.{ }^{11}, \mathrm{Phe}^{13}, \mathrm{Nle}{ }^{14}\right] \mathrm{BN}(6-14)$ showed that both metallopeptides have good to moderate affinity to the GRP and the NMB receptor and no affinity to the BB3 receptor. The affinities are about ten times lower than those of truncated $\mathrm{BN}(7-14)$ and intact $\mathrm{BN}$ derivatives coupled to bifunctional tetra-amines, which show $\mathrm{IC}_{50}$ values between 0.2 and $2 \mathrm{nmol} / 1$ to the GRP receptor and, with one exception, also to the NMB receptor. The best of the ${ }^{99 \mathrm{~m}}$ Tc-labelled compounds have $K_{\mathrm{d}}$ values and $\mathrm{IC}_{50}$ values below $1 \mathrm{nmol} / \mathrm{l}$ [19]. There was no significant difference in affinity between the peptides metallated with $\mathrm{Ga}^{3+}$ or $\mathrm{Lu}^{3+}$. This is in contrast to DOTA-octreotide derivatives; these conjugates show a distinctly improved binding affinity when labelled with radiogallium [32, 34].

The rate of internalisation into PC-3 cells was similar for the two radiopeptides and somewhat more efficient than the internalisation of the panbombesin ligands studied previously in the same assay and under the same conditions [17]. This similarity does not reflect the distinct difference in binding affinity. The high rate of internalisation of the two radiopeptides indicates that they are agonists.

Efflux curves of $\left[{ }^{67} \mathrm{Ga}\right]-D O T A-P E S I N$ and $\left[{ }^{177} \mathrm{Lu}\right]-$ DOTA-PESIN from the PC-3 cells after $2 \mathrm{~h}$ of internalisation are essentially identical and their half-lives are $\geq 20 \mathrm{~h}$, which is much longer than those of the panbombesin derivatives. Efflux studies were also performed with $\left[{ }^{177} \mathrm{Lu}-\right.$ DOTA-Aoc]BN(7-14) but only up to $2 \mathrm{~h}$ [18]. Within this time period the two compounds behave similarly. $\left[{ }^{67} \mathrm{Ga}-\right.$ DOTA $\left.^{0}-\mathrm{PEG}_{2}, \mathrm{D}_{\mathrm{Tyr}}{ }^{6}, \beta-\mathrm{Ala}^{11}, \mathrm{Thi}^{13}, \mathrm{Nle}^{14}\right] \mathrm{BN}(7-14)$ and the corresponding ${ }^{177} \mathrm{Lu}$-labelled radiopeptide externalise 
with a somewhat different rate $\left(t_{1 / 2}\left({ }^{67} \mathrm{Ga}\right)=16.5 \pm 2.4 \mathrm{~h} ; t_{1 / 2}\right.$ $\left.\left({ }^{177} \mathrm{Lu}\right)=12.8 \pm 1.4 \mathrm{~h}\right)[31]$. A prolonged intracellular retention is of importance if long-lived radionuclides are to be used in therapy studies.

After administration of $\left[{ }^{67} \mathrm{Ga} /{ }^{177} \mathrm{Lu}\right]$-DOTA-PESIN, clearance from the circulation was fast and whole body clearance proceeded via the urinary system, unlike the positively charged ${ }^{99 \mathrm{~m}} \mathrm{Tc}-\mathrm{N}_{4}$-labelled $\mathrm{BN}$ analogues, which are partly excreted via the hepatobiliary tract $[19,27]$. Clearance from GRP receptor-negative tissues was also rapid except from the kidneys.

Initially, tumour uptake was very high $(14.8 \% \mathrm{IA} / \mathrm{g}$ at $1 \mathrm{~h}$ ), approaching the uptake of the best radiopeptides studied so far in the PC-3 tumour model [27]. This new radiopeptide has a high tumour-to-liver ratio which may make it even somewhat superior to the best ${ }^{99 \mathrm{~m}} \mathrm{Tc}$-labelled peptides [19]. The uptake in tumour, pancreas, intestine and pituitary was specific and receptor mediated, as shown by the co-injection of cold peptide, indicating that these organs are also GRP receptor positive. Unlike others [16, 35, 36] we also found a decrease in the kidney uptake when a peptide-blocking dose was administered, whereas a substantial reduction in kidney uptake upon blocking was also shown recently by use of an ${ }^{18} \mathrm{~F}$-labelled $\mathrm{Lys}^{3}-\mathrm{BN}$ derivative [37]. The fast background clearance of the radiogallium peptide renders $\left[{ }^{68} \mathrm{Ga}\right]$-DOTA-PESIN an ideal radiotracer for PET imaging. The relatively fast initial washout from the tumour may be explained by radioligand not being internalised and being metabolised during its presence in the tumour compartment.

The structural entities which confer the suitable pharmacokinetic properties to this molecule most likely reside in the $\mathrm{PEG}_{4}$ spacer. Preliminary data using shorter and longer spacers indicate that $\mathrm{PEG}_{4}$ has an optimal length. The lack of affinity to the BB3 receptor may be advantageous as this orphan receptor is expressed in the human pancreas.

\section{Conclusion}

Despite the relatively low binding affinity of $\left[\mathrm{Lu}^{\mathrm{III}}, \mathrm{Ga}^{\mathrm{III}}\right]$ DOTA-PESIN the corresponding radiopeptides show suitable pharmacokinetics in the PC-3 tumour-bearing mouse model, with high tumour uptake and relatively slow washout from the tumour. The radiopeptides show superior tumour-to-liver and suitable tumour-to-kidney ratios in comparison with our earlier published radiopeptides and even with the best ${ }^{99 \mathrm{~m}} \mathrm{Tc}$-labelled $\mathrm{BN}$ analogues. This renders the new peptides suitable for clinical studies.

Acknowledgements We thank the Swiss National Science Foundation (Grant No. 3100A0-100390) and the European Network of Excellence 'EMIL' (European Molecular Imaging Laboratories, Grant No. 503569) for financial support of this work and Novartis Basel for analytical support.

\section{References}

1. Reubi JC. Peptide receptors as molecular targets for cancer diagnosis and therapy. Endocr Rev 2003;24:389-427.

2. Behr TM, Behe M, Becker W. Diagnostic applications of radiolabeled peptides in nuclear endocrinology. Q J Nucl Med 1999;43:268-80.

3. Heppeler A, Froidevaux S, Eberle AN, Maecke HR. Receptor targeting for tumor localisation and therapy with radiopeptides. Curr Med Chem 2000;7:971-94.

4. Breeman WA, de Jong M, Kwekkeboom DJ, Valkema R, Bakker $\mathrm{WH}$, Kooij PP, et al. Somatostatin receptor-mediated imaging and therapy: basic science, current knowledge, limitations and future perspectives. Eur J Nucl Med 2001;28:1421-9.

5. De Jong M, Kwekkeboom D, Valkema R, Krenning EP. Radiolabelled peptides for tumour therapy: current status and future directions. Plenary lecture at the EANM 2002. Eur J Nucl Med Mol Imaging 2003;30:463-9.

6. Anderson CJ, Welch MJ. Radiometal-labeled agents (non-technetium) for diagnostic imaging. Chem Rev 1999;99:2219-34.

7. Schmitt A, Bernhardt P, Nilsson O, Ahlman H, Kolby L, Maecke $\mathrm{HR}$, et al. Radiation therapy of small cell lung cancer with ${ }^{177} \mathrm{Lu}-$ DOTA-Tyr ${ }^{3}$-octreotate in an animal model. J Nucl Med 2004;45:1542-8.

8. Kwekkeboom DJ, Bakker WH, Kooij PP, Konijnenberg MW, Srinivasan A, Erion JL, et al. $\left.{ }^{[177} \mathrm{Lu}-\mathrm{DOTA}^{0} \mathrm{Tyr}^{3}\right]$ octreotate: comparison with $\left[{ }^{111} \mathrm{In}-\mathrm{DTPA}{ }^{0}\right]$ octreotide in patients. Eur J Nucl Med 2001;28:1319-25.

9. Maecke HR, Hofmann M, Haberkorn U. ${ }^{68}$ Ga-labeled peptides in tumor imaging. J Nucl Med 2005;46 Suppl 1:172S-8S.

10. Meyer GJ, Maecke H, Schuhmacher J, Knapp WH, Hofmann M. ${ }^{68}$ Ga-labelled DOTA-derivatised peptide ligands. Eur J Nucl Med Mol Imaging 2004;31:1097-104.

11. Reubi JC, Wenger S, Schmuckli-Maurer J, Schaer JC, Gugger M. Bombesin receptor subtypes in human cancers: detection with the universal radioligand ${ }^{125} \mathrm{I}-\left[\mathrm{D}-\mathrm{Tyr}^{6}\right.$, beta-Ala ${ }^{11}, \mathrm{Phe}^{13}, \mathrm{Nl}^{14}$ ] bombesin(6-14). Clin Cancer Res 2002;8:1139-46.

12. Breeman WA, Hofland LJ, de Jong M, Bernard BF, Srinivasan A, Kwekkeboom DJ, et al. Evaluation of radiolabelled bombesin analogues for receptor-targeted scintigraphy and radiotherapy. Int J Cancer 1999;81:658-65.

13. Van de Wiele C, Dumont F, Vanden Broecke R, Oosterlinck W, Cocquyt V, Serreyn R, et al. Technetium-99m RP527, a GRP analogue for visualisation of GRP receptor-expressing malignancies: a feasibility study. Eur J Nucl Med 2000;27:1694-9.

14. Smith CJ, Volkert WA, Hoffman TJ. Gastrin releasing peptide (GRP) receptor targeted radiopharmaceuticals: a concise update. Nucl Med Biol 2003;30:861-8.

15. Hoffman TJ, Gali H, Smith CJ, Sieckman GL, Hayes DL, Owen $\mathrm{NK}$, et al. Novel series of ${ }^{111}$ In-labeled bombesin analogs as potential radiopharmaceuticals for specific targeting of gastrinreleasing peptide receptors expressed on human prostate cancer cells. J Nucl Med 2003;44:823-31.

16. Chen X, Park R, Hou Y, Tohme M, Shahinian AH, Bading JR, et al. microPET and autoradiographic imaging of GRP receptor expression with ${ }^{64} \mathrm{Cu}$-DOTA-[ $\left.\mathrm{Lys}^{3}\right]$ bombesin in human prostate adenocarcinoma xenografts. J Nucl Med 2004;45:1390-7.

17. Zhang H, Chen J, Waldherr C, Hinni K, Waser B, Reubi JC, et al. Synthesis and evaluation of bombesin derivatives on the basis of pan-bombesin peptides labeled with indium-111, lutetium-177, and yttrium-90 for targeting bombesin receptor-expressing tumors. Cancer Res 2004;64:6707-15.

18. Smith CJ, Gali H, Sieckman GL, Hayes DL, Owen NK, Mazuru $\mathrm{DG}$, et al. Radiochemical investigations of ${ }^{177}$ Lu-DOTA-8-AocBBN[7-14] $\mathrm{NH}_{2}$ : an in vitro/in vivo assessment of the targeting 
ability of this new radiopharmaceutical for PC-3 human prostate cancer cells. Nucl Med Biol 2003;30:101-9.

19. Nock BA, Nikolopoulou A, Galanis A, Cordopatis P, Waser B, Reubi JC, et al. Potent bombesin-like peptides for GRP-receptor targeting of tumors with ${ }^{99 \mathrm{~m}} \mathrm{Tc}$ : a preclinical study. J Med Chem 2005;48:100-10.

20. Baidoo KE, Lin KS, Zhan Y, Finley P, Scheffel U, Wagner HN Jr. Design, synthesis, and initial evaluation of high-affinity technetium bombesin analogues. Bioconjug Chem 1998;9:218-25.

21. Scopinaro F, De Vincentis G, Varvarigou AD, Laurenti C, Iori F, Remediani $\mathrm{S}$, et al. ${ }^{99 \mathrm{~m}} \mathrm{Tc}$-bombesin detects prostate cancer and invasion of pelvic lymph nodes. Eur J Nucl Med Mol Imaging 2003;30:1378-82.

22. La Bella R, Garcia-Garayoa E, Langer M, Blauenstein P, BeckSickinger AG, Schubiger PA. In vitro and in vivo evaluation of a ${ }^{99 \mathrm{~m}} \mathrm{Tc}(\mathrm{I})$-labeled bombesin analogue for imaging of gastrin releasing peptide receptor-positive tumors. Nucl Med Biol 2002;29:553-60.

23. Smith CJ, Sieckman GL, Owen NK, Hayes DL, Mazuru DG, Kannan R, et al. Radiochemical investigations of gastrin-releasing peptide receptor-specific $\left[{ }^{99 \mathrm{~m}} \mathrm{Tc}(\mathrm{X})(\mathrm{CO})_{3}\right.$-Dpr-Ser-Ser-Ser-GlnTrp-Ala-Val-Gly-His-Leu-Met- $\left(\mathrm{NH}_{2}\right)$ ] in PC-3, tumor-bearing, rodent models: syntheses, radiolabeling, and in vitro/in vivo studies where $\mathrm{Dpr}=2,3$-diaminopropionic acid and $\mathrm{X}=\mathrm{H}_{2} \mathrm{O}$ or $\mathrm{P}$ $\left(\mathrm{CH}_{2} \mathrm{OH}\right)_{3}$. Cancer Res 2003;63:4082-8.

24. Chen J, Nguyen H, Metcalfe E, Eaton S, Arunachalam T, Raju N. Formulation and in vitro metabolism studies with ${ }^{177} \mathrm{Lu}$-AMBA; a radiotherapeutic compound that targets gastrin releasing peptide receptors. Eur J Nucl Med Mol Imaging 2004;31 Suppl 2:S281.

25. Van de Wiele C, Dumont F, Dierckx RA, Peers SH, Thornback JR, Slegers G, et al. Biodistribution and dosimetry of ${ }^{99 \mathrm{~m}} \mathrm{Tc}-$ RP527, a gastrin-releasing peptide (GRP) agonist for the visualization of GRP receptor-expressing malignancies. J Nucl Med 2001;42:1722-7.

26. Hoffmann T, Simpson S, Smith C, Simmons J, Sieckman G, Higginbotham $\mathrm{C}$, et al. Accumulation and retention of Tc-99 mRP527 by GRP receptor expressing tumors in scid mice. J Nucl Med 1999;40:104P (Abstract No. 419).

27. Nock B, Nikolopoulou A, Chiotellis E, Loudos G, Maintas D, Reubi JC, et al. [ $\left.{ }^{99 \mathrm{~m}} \mathrm{Tc}\right]$ Demobesin 1 , a novel potent bombesin analogue for GRP receptor-targeted tumour imaging. Eur J Nucl Med Mol Imaging 2003;30:247-58.

28. Schuhmacher J, Maier-Borst W. A new ${ }^{68} \mathrm{Ge} /{ }^{68} \mathrm{Ga}$ radioisotope generator system for production of ${ }^{68} \mathrm{Ga}$ in dilute $\mathrm{HCl}$. Int J Appl Radiat Isot 1981;32:31-6.

29. Markwalder R, Reubi JC. Gastrin-releasing peptide receptors in the human prostate: relation to neoplastic transformation. Cancer Res 1999;59:1152-9.

30. Fleischmann A, Laderach U, Friess H, Buechler MW, Reubi JC. Bombesin receptors in distinct tissue compartments of human pancreatic diseases. Lab Invest 2000;80:1807-17.

31. Schuhmacher J, Zhang H, Doll J, Maecke HR, Matys R, Hauser $\mathrm{H}$, et al. GRP receptor-targeted PET of a rat pancreas carcinoma xenograft in nude mice with a ${ }^{68} \mathrm{Ga}$-labeled bombesin(6-14) analog. J Nucl Med 2005;46:691-9.

32. Heppeler A, Froidevaux S, Mäcke HR, Jermann E, Béhé M, Powell P, et al. Radiometal-labelled macrocyclic chelator-derivatised somatostatin analogue with superb tumour-targeting properties and potential for receptor-mediated internal radiotherapy. Chemistry A European Journal 1999;5:1016-23.

33. Rogers BE, Manna DD, Safavy A. In vitro and in vivo evaluation of a ${ }^{64} \mathrm{Cu}$-labeled polyethylene glycol-bombesin conjugate. Cancer Biother Radiopharm 2004;19:25-34.

34. Reubi JC, Schar JC, Waser B, Wenger S, Heppeler A, Schmitt JS, et al. Affinity profiles for human somatostatin receptor subtypes SST1-SST5 of somatostatin radiotracers selected for scintigraphic and radiotherapeutic use. Eur J Nucl Med 2000;27:273-82.

35. Lin KS, Luu A, Baidoo KE, Hashemzadeh-Gargari H, Chen MK, Brenneman K, et al. A new high affinity technetium-99mbombesin analogue with low abdominal accumulation. Bioconjug Chem 2005;16:43-50.

36. Rogers BE, Bigott HM, McCarthy DW, Della Manna D, Kim J, Sharp TL, et al. MicroPET imaging of a gastrin-releasing peptide receptor-positive tumor in a mouse model of human prostate cancer using a ${ }^{64} \mathrm{Cu}$-labeled bombesin analogue. Bioconjug Chem 2003; 14:756-63.

37. Zhang X, Cai W, Cao F, Schreibmann E, Wu Y, Wu JC, et al. ${ }^{18} \mathrm{~F}$ labeled bombesin analogs for targeting GRP receptor-expressing prostate cancer. J Nucl Med 2006;47:492-501. 